\title{
MOLECULAR CLONING OF THE HUMAN HISTAMINE H2 RECEPTOR
}

\author{
Ira Gantz ${ }^{1}$, Gerd Munzert ${ }^{2}$, Takao Tashiro², Matthias Schäffer ${ }^{2 *}$, Lidong Wang ${ }^{2}$, John DelValle ${ }^{2}$, \\ and Tadataka Yamada2,3
}
Departments of ${ }^{1}$ Surgery, ${ }^{2}$ Internal Medicine, and ${ }^{3}$ Physiology, University of Michigan Medical Center, Ann Arbor, MI

Received July 8, 1991

SUMMARY: We utilized the technique of polymerase chain reaction with oligonucleotide primers based upon the nucleotide sequence of the canine $\mathrm{H} 2$ histamine receptor gene which we recently isolated to clone its human homologue. Transfection of a construct of this gene in Colo-320 DM cells led to the expression of a receptor that bound to [methyl-3H] tiotidine and was linked to $3^{\prime}, 5^{\prime}$ cyclic adenosine monophosphate (cAMP) generation in response to histamine. Both cAMP generation and [methyl-3H] tiotidine binding were inhibited with the $\mathrm{H} 2$ histamine receptor selective antagonist cimetidine but not diphenhydramine or thioperamide which are, respectively, $\mathrm{H} 1$ and $\mathrm{H} 3$ histamine receptor antagonists. These data confirm that we have successfully cloned a novel gene encoding the human H2 histamine receptor. 1991 Academic Press, Inc.

The importance of histamine in the regulation of gastric acid secretion was confirmed by the development of an antagonist that was specific for a subtype of histamine receptor subclass of histamine receptors labeled $\mathrm{H} 2$ (1). Indeed, the development of $\mathrm{H} 2$ receptor antagonists had a profound effect on the treatment of peptic ulcer disease. Despite the extraordinary physiological and pharmacological significance of the $\mathrm{H} 2$ histamine receptor, little is known about its structure or function in man. Recently we cloned a gene encoding the canine gastric parietal cell $\mathrm{H} 2$ histamine receptor using the techniques of polymerase chain reaction (PCR) with degenerate oligonucleotide primers based upon homology tc $u$ ther receptors known to be linked to guanine nucleotide binding proteins (2). In the current report we have utilized this gene to clone the human homologue of the canine $\mathrm{H} 2$ receptor and by expressing it in a human colon cancer cell line (Colo-320 DM), we have confirmed its identity.

\section{MATERIALS AND METHODS}

Isolation of RNA. Human gastric fundic mucosa was obtained from a fresh surgical specimen and placed into liquid nitrogen for storage. The frozen tissue was pulverized and total RNA was extracted by the acid guanidinium thiocyanate-phenol-chloroform method (3). Poly A+RNA obtained by oligo d(T) cellulose chromatography of the total RNA served as a template for cDNA synthesis using the avian myeloblastosis virus reverse transcriptase (Seikagaku, Rockville, MD.). The cDNA thus obtained functioned as a template for the polymerase chain reaction with the oligonucleotide primers described below.

\footnotetext{
*Present address: Department of Internal Medicine, Universität Kiel, Germany.
} 
Polymerase Chain Reaction. Three heptadecanucleotides that had been used to sequence the canine H2 clone were pooled and used as 5' PCR primers (5'CAGGATGATATCTAACG3', 5'GTGTCGTTGGCTATCACC3', 5'TCCATTCTTAACCTCTT3') (2). A reverse complement heptadecanucleotide which was a degenerate oligonucleotide corresponding to an area in the fifth transmembrane domain of the canine $\mathrm{H} 2$ receptor (5'AAXGTXACYAZYCCZTC3'; $X=G$ or I,

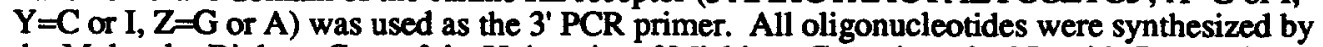
the Molecular Biology Core of the University of Michigan Gastrointestinal Peptide Research Center using an Applied Biosystems 380B DNA synthesizer. The conditions for the polymerase chain reaction were as follows: denaturation for $1.5 \mathrm{~min}$ at $94^{\circ} \mathrm{C}$, annealing for $2 \mathrm{~min}$ at $45^{\circ} \mathrm{C}$, and extension for $4 \mathrm{~min}$ at $72^{\circ} \mathrm{C}$. The reaction was carried out for 30 cycles and then $20 \%$ of the product was added to fresh buffer and subjected to another 30 cycles. The final reaction products were phenol extracted and then ethanol precipitated. The DNA was blunt-ended via the Klenow reaction and the products of the reaction were electrophoresed on a $1 \%$ NuSieve, $1 \%$ Seaplaque gel (FMC, , Rockland, ME). Two bands of approximately $575 \mathrm{bp}$ and $400 \mathrm{bp}$ (Figure 1) were obtained. The larger band was cut out of the gel and subcloned directly into the M13 sequencing vector (4). Dideoxynucleotide sequencing was then performed by the chain termination method of Sanger (5) using Sequenase Version 2 (USB, Cleveland, Ohio).

Genomic Cloning. The partial length PCR derived clone was random primed (6) with 32P and used as a probe to screen a human genomic library (Clontech, Palo Alto, CA). Under high stringency hybridization $\left[0.9 \mathrm{M}\right.$ sodium chloride $0.09 \mathrm{M}$ sodium citrate $(6 \times \mathrm{SSC}), 65^{\circ} \mathrm{C}$ ] and wash conditions $\left[0.1 \times \mathrm{SSC}, 55^{\circ} \mathrm{C}\right]$ a single clone exhibited a positive hybridization signal with the probe. The DNA insert in this clone was mapped with restriction endonucleases and a fragment flanked by two Pst I sites that contained the sequence derived by polymerase chain reaction was inserted into the M13 vector and its nucleotide sequence obtained. A second fragment flanked by two Pst I sites corresponding to the 3' portion of the coding region (bp 916 to the stop codon) and a portion of the untranslated $3^{\prime}$ region of the gene was also subcloned into M13 for nucleotide sequencing.

Expression Experiments. The presumed full length coding region of the receptor gene was subcloned into CMVneo, a PUC13 based vector that also contains the lacUV5-SV40 promoter (440 bp), Tn5-neo (1400 bp), SV40 splice site and polyadenylation signal (320 bp), CMV promoter $(700 \mathrm{bp})$ and human growth hormone polyadenylation signal $(700 \mathrm{bp})(7)$. Cultures of the human colonic adenocarcinoma cell line Colo-320DM (American Type Culture Collection, CCL 220) were transfected with this vector using the technique of calcium phosphate co-precipitation (8). Permanently transfected Colo-320 DM clones were selected by adding $1 \mathrm{mg} / \mathrm{ml}$ of the neomycin analogue G418 to the culture medium. For binding studies, the selected clones were plated and grown to confluence in $2.4 \times 1.7 \mathrm{~cm}$ multi-well plates. The culture medium was removed and cells were washed twice with Earle's balanced salt solution containing $0.1 \%$ bovine serum albumin. An aliquot $(36 \mathrm{nCi})$ of [methyl-3H]-tiotidine $(87 \mathrm{Ci} / \mathrm{mmol}$; Dupont, Boston $\mathrm{MA})$ was added to the cultures in the presence of either cimetidine or diphenhydramine and after one hour of incubation, the medium was removed by aspiration. The cells were washed twice with 0.2

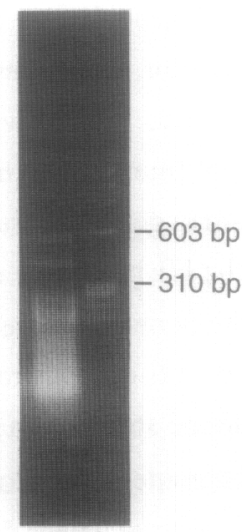

Figure 1. Gel (1\% Nusicve, 1\% Seaplaque) electrophoresis of polymcrase chain reaction products from human gastric fundus mucosa (left lane). The size markers are included in the right lane. 
M sodium phosphate $0.15 \mathrm{M} \mathrm{NaCl}, \mathrm{pH} \mathrm{7.4,} \mathrm{lysed} \mathrm{with} 1 \%$ Triton $\mathrm{X}-100$, and the radioactivity was quantified. Maximum binding was determined by incubation of [methyl-3H]-tiotidine with transformed Colo-320DM cells in the absence of antagonists. Non-specific binding, which was subtracted from total binding to obtain specific binding, was determined as the amount of label remaining bound in the presence of $10^{-5}$ cimetidine. Transfected cells were incubated in Earle's balanced salt solution with varying concentrations of histamine for $60 \mathrm{~min}$ at $37^{\circ} \mathrm{C}$ after a $60 \mathrm{~min}$ pre-incubation in medium with or without addition of cimetidine $\left(10^{-4} \mathrm{M}\right)$. Ice cold $30 \%$ trichloroacetic acid was added to stop the reaction and precipitate the cellular protein. After centrifugation for $10 \mathrm{~min}$ at $1900 \mathrm{x}$ g, the supernatant was ether extracted, lyophilized, and resuspended in $50 \mathrm{mM}$ Tris, $2 \mathrm{mM}$ EDTA, pH 7.5. The content of 3', 5' cyclic adenosine monophosphate (cAMP) was measured by competitive protein binding assay using an Amersham kit (Arlington Heights, Il).

Northern Blotting. Total RNA was obtained by the acid guanidinium method and hybridization was performed using conditions previously described (9). The presumed coding region of the receptor gene that had been labeled with $32 \mathrm{P}$ by random priming served as the probe.

\section{RESULTS AND DISCUSSION}

Of the four clones obtained by subcloning the 575 bp PCR fragment into M13, one clone had approximately $83 \%$ nucleotide homology to a region of the gene encoding the canine histamine $\mathrm{H} 2$ receptor. Using this clone as a probe to screen a human genomic library, we obtained a full length clone that exhibited $88 \%$ nucleotide homology with the canine histamine $\mathrm{H} 2$ receptor gene (Figure 2). The amino acid homology (87\%) of the proteins encoded by the two clones is comparable (Figure 3) with $92 \%$ overall similarity when conservative amino acid substitutions are considered. The regions of greatest homology between the two clones were the putative transmembrane regions of the receptor (table 1). Studies by mutational analysis of the beta adrenergic receptor have indicated that two serine residues in the fifth transmembrane receptor are important for catecholamine binding. By analogy, the Asp ${ }^{186}$ and $\mathrm{Thr}^{190}$ in the fifth transmembrane domain of the canine histamine $\mathrm{H} 2$ receptor may have the potential to interact by hydrogen bonding with the imidazole ring of the histamine molecule. This particular region of the cloned human gene (Val ${ }^{185}$ - Leu ${ }^{193}$ ) exhibited $100 \%$ homology at both the nucleotide and amino acid levels with the canine histamine $\mathrm{H} 2$ receptor gene. Northem blot analysis of human fundic mucosa (Figure 4) revealed a band of hybridization of approximately $4.8 \mathrm{~Kb}$ which corresponds to the predominant messenger RNA in the canine fundus (2).

To confirm the identity of this human gene that we obtained and demonstrated to be homologous to the canine histamine $\mathrm{H} 2$ receptor, we expressed the gene in a human cell line (Colo-320DM) and conducted functional assays. As shown in Figure 5, cimetidine, an H2 selective antagonist, displaced the binding of [methyl- ${ }^{3} \mathrm{H}$ ] tiotidine (another $\mathrm{H} 2$ receptor antagonist) to cells transfected with the human gene construct in a dose dependent fashion with an ED50 of $5 \times 10^{-8} \mathrm{M}$. In contrast, neither the $\mathrm{H} 1$ histamine receptor antagonist diphenhydramine nor the $\mathrm{H} 3$ histamine receptor antagonist thioperamide were able to displace labeled tiotidine binding. As shown in Figure 6, transfected cells demonstrated dose-dependent increases in cellular cAMP content in response to histamine stimulation reaching a maximum of $366 \pm 40 \%$ of control (mean $\pm \mathrm{SE}, \mathrm{n}=3$ ) at the $10^{-5} \mathrm{M}$ histamine dose. Control non-transfected Colo-320 DM cells failed to demonstrate a response to histamine. These data confirm that the gene that we cloned encoded the human homologue of the canine $\mathrm{H} 2$ histamine receptor. Although in the published 
1 ATGGCACCCAATGGCACAGCCTCTTCCTTTTGCCTGGACTCTACCGCATGCAAGATCACC

$$
\begin{array}{lllllll}
\text { AT T I C } & G & T & \text { C TC } & \text { G }
\end{array}
$$

61 ATCACCGTGGTCCTTGCGGTCCTCATCCTCATCACCGTTGCTGGCAATGTGGTCGTCTGT 120 $G$ G CA $\mathrm{T} \quad$ A C C C G C

$121 \overline{\text { CTGGCCGTGGGCTTGAACCGCCGGCTCCGCAACCTGACCAATTGTTTCATCGTGTCCTTG }} 180$

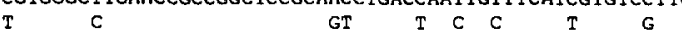
Ir

181 GCTATCACTGACCTGCTCCTCGGCCTCCTGGTGCTGCCCTTCTCTGCCATCTACCAGCTG

$$
C \mathrm{~T} \quad \mathrm{G} T \mathrm{~T} \text { A }
$$

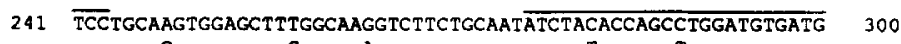

301 CTCTGCACAGCCTCCATTCTTAACCTCTTCATGATCAGCCTCGACCGGTACTGCGCTGTC 360 $G \quad G \quad C$ C $T$ T

361 ATGGACCCACTGCGGTACCCTGTGCTGGTCACCCCAGTTCGGGTCGCCATCTCTCTGGTC 420 $\begin{array}{lllllll}C T & C & C & T A & C & G & T\end{array}$

421 TTAATTGGgTCATCTCCATTACCCTGICCTTTCTGTCTATCCACCTGGGGTGGAACAGC 460 C C $\quad T$ T

481 AGgAaCGAGACCAGCAAGgGCAATCATACCACCTCTAAGTGCAAAGTCCAGgTCAATGAa SqD

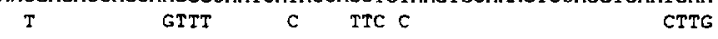

$541 \overline{\text { GTGTACGGGCTGGTGGATGGGCTGGTCACCTTCTACCTCCCGCTACTGATCATGTGCATC }}$ 600 $T$ CT

601 ACCTACTACCGCATCITCAAGgTCGCCCggGatcaggCCAAGAGgATCAATCACATtAGC

661 TCCTGGAAGGCAGCCACCATCAGGGAGCACAAAGCCACAGTGACACTGGCCGCCGTCATG

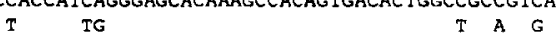

781 GGGGATGATGCCATCAATGAGGTGTTAGAAGCCATCGTTCIGTGGCTGGGCTATGCCAAC 840 CT $\mathrm{T} \quad \mathrm{G}$

Q41 TCAGCCCTGAACCCCATCCTGTATGCTGCGCTGAACAGAGACTTCCGCACCGGGTACCAA $G$ CA A G CA

901 CAGCTCTTCTGCTGCAGGCTGGCCAACCGCAACTCCCACAAAACTTCTCTGAGGTCCAAC 960 C C G A TG GG G

961 GCCTCTCAGCTGTCCAGGACCCAAAGCCGAGAACCCAGGCAACAGGAAGAGAaACCCCTG 1020

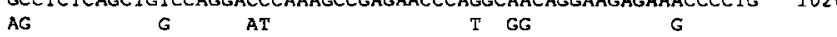

1021 AagctCCAGGTGTGGAGTGGGACAGAagTCACGGCCCCCCAGGGAGCCACAGACAGGTAA 1080 G A T GA

Figure 2. The nucleotide sequence of the human $\mathrm{H} 2$ histamine receptor gene. The canine $\mathrm{H} 2$ histamine receptor gene was identical except as noted beneath the human gene nucleotide sequence. The initiation codon (ATG) and termination codon (TAA) are italicized. The sequences encoding the seven putative transmembrane regions are indicated by the over lines.

1 MAPNGTASSFCLDSTACKITI TVVLAVLILITVAGNVVVCLAVGLNRRLRNLTNCFIVSL IS $G$ PP $R$ VS T

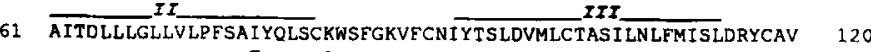
AITDLLLGLLVLPFSAIYQLSCKWSFGKVECNTYTSLDVMLCTASIENLFMISLDRYCAV
F $\mathrm{R}$

121 MDPLRYPVLVTPVRVAISLVLIWVISITLSF LSI HLGWNSRNETSKGNHTTSKCKVQVNE 180 I I V V SF IP

181 VYGLVDGLVTFYLPLLIMCITYYRIFKVARDQAKR INHISSWKAATIREHKATVTLAAVM 240

241 GAFIICWFPYFTAFVYRGLRGDDAINEVLEAIVLWLGYANSALNP ILYAALNRDFRTGYO

41 GAFIICWFPYFTAFVYRGLRGDDAINEVLEAIVLWLGYANSALNP ILYAALNRDFRTGYO 300

301 QLFCCRLANRNSHKTSLRSNASQLSRTQSREPRQQEEKPLKLQVWSGTEVTAPQGATOR* 360

$$
R \text { P SH AQE S A N MR R }
$$

Figure 3. Amino acid sequence of the human $\mathrm{H} 2$ histamine receptor. The canine $\mathrm{H} 2$ histamine receptor was identical except as noted by different amino acids beneath the human receptor sequence. The sequences encoding the seven putative transmembrane regions are indicated by the over lines. 
TABLE I

HOMOLOGY OF HUMAN AND CANINE H2 HISTAMINE RECEPTORS

\begin{tabular}{|c|c|c|c|}
\hline \multirow[t]{2}{*}{ REGION } & \multirow{2}{*}{$\begin{array}{l}\text { NUCLEOTIDE } \\
\text { (\% IDENTITY) }\end{array}$} & \multicolumn{2}{|c|}{$\begin{array}{l}\text { AMINO ACID } \\
\end{array}$} \\
\hline & & (\% SIMILARITY) & (\% IDENTITY) \\
\hline \multicolumn{4}{|l|}{ TRANSMEMBRANE } \\
\hline 1 & 86 & 95 & 91 \\
\hline 2 & 92 & 100 & 96 \\
\hline 3 & 89 & 100 & 100 \\
\hline 4 & 92 & 100 & 96 \\
\hline 5 & 92 & 100 & 96 \\
\hline 6 & 86 & 96 & 96 \\
\hline 7 & 86 & 95 & 86 \\
\hline \multicolumn{4}{|c|}{ INTRACYTOPLASMIC } \\
\hline 1 & 82 & 92 & 92 \\
\hline 2 & 88 & 95 & 90 \\
\hline 3 & 90 & 97 & 83 \\
\hline 4 & 86 & 82 & 79 \\
\hline \multicolumn{4}{|l|}{ EXTRACELLULAR } \\
\hline 1 & 79 & 82 & 64 \\
\hline 2 & 91 & 100 & 91 \\
\hline 3 & 78 & 76 & 76 \\
\hline 4 & 96 & 100 & 89 \\
\hline
\end{tabular}

literature there are only allusions as to the linkage of the human $\mathrm{H} 2$ to cAMP generation through a stimulatory guanine nucleotide binding protein $\left(\mathrm{G}_{\mathrm{s}}\right)(2)$, our data confirm this linkage. Studies by mutational analysis of the beta adrenergic region, which is associated with cAMP generation via $G_{s}$, indicate that the critical areas for interaction of the receptor protein to $G_{S}$ resides in the AKR sequence of the amino terminus and the EHKA sequence at the carboxyl terminus of the third

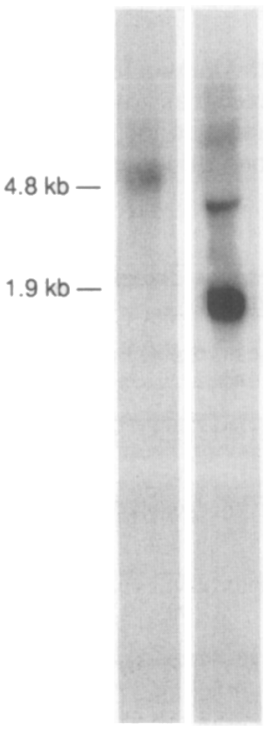

Figure 4. Northern blot analysis of total RNA from human fundic mucosa (left) and transfected Colo-320 DM cells (right) with a random primed human $\mathrm{H} 2$ histamine receptor probe. 

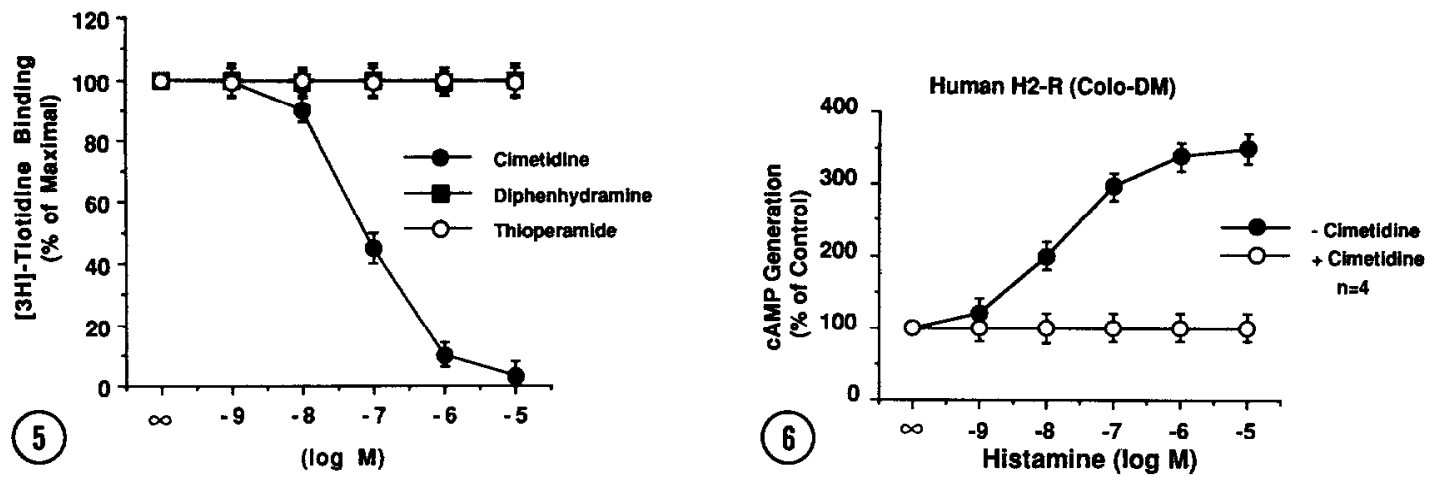

Figure 5. Methyl $-[3 \mathrm{H}]$ tiotidine binding to transfected Colo-320DM cells. Binding was dose dependently reversed by cimetidine, while diphenhydramine and thioperamide had no effect. Tiotidine did not bind to non transfected Colo-320DM cells (data not shown).

Figure 6. Effect of histamine on cAMP accumulation in transfected Colo-320DM cells. Histamine dose dependently increased cAMP accumulation with a maximal effect and half maximal effect observed at $10^{-5 M}$ and $5 \times 10^{-8} \mathrm{M}$ respectively. Histamine's stimulatory effect on cAMP generation was abolished by pretreatment with cimetidine $\left(10^{-5 \mathrm{M}}\right)$.

intracytoplasmic loop (10). Both the canine $\mathrm{H} 2$ histamine receptor, the action of which has been shown to be mediated via $\mathrm{G}_{s}$, and the newly cloned human histamine $\mathrm{H} 2$ receptor conserve these amino acids. It is important to note, however, that the demonstrated linkage between $\mathrm{H} 2$ histamine receptors and cAMP generation does not preclude mediation of histamine action via other signal transduction pathways. In a human leukemia cell line (HL60) and in isolated rabbit gastric parietal cells, activation of an intracellular pathway leading to $\mathrm{Ca}^{+2}$ mobilization has been identified $(11,12)$. Further studies in cells transfected with a construct of our newly cloned human $\mathrm{H} 2$ histamine receptor gene may determine whether the multiple signal transduction pathways activated by $\mathrm{H} 2$ receptors is mediated by a single or multiple receptor subtypes.

The histamine $\mathrm{H} 2$ receptor plays a critically important role in numerous physiological functions. Antagonism of one of these functions, stimulation of gastric acid secretion, has been the basis of an enormous world-wide pharmaceutical industry market for treatment of acid/peptic disorders of the intestine. Structural and functional characterization of the human $\mathrm{H} 2$ histamine receptor via studies with the gene that we have successfully cloned may help to elucidate the pathogenesis of these disorders as well as aid in their treatment.

\section{ACKNOWLEDGMENTS}

This work was supported by NIH grant RO1DK34306, RO1DK 33500 and funds from the University of Michigan Gastrointestinal Peptide Research Center (NIH grant P30DK34933). Dr. Gantz is a recipient of a Veterans Administration Research Associate Award. Dr. Munzert is the recipient of the Deutsche Forschungsgemeinschaft grant Mu 835/1-1. Dr. Schäffer is recipient of the Deutsche Forschungsgemeinschaft grant Scha 453/1-1. Dr. DelValle is recipient of a Clinical Investigator Award (NIH grant K08-DK01823). We thank II Song for synthesizing our oligonucleotides. 


\section{REFERENCES}

1. Feldman, M., Burton, M. E. (1990) New Engl. J. Med. 323, 1672-1680.

2. Gantz, I., Schaffer, M., DelValle, J., Logsdon, C., Campbell, V., Uhler, M., Yamada, T. (1991) Proc. Nat. Acad. Sci. USA 88, 429-433.

3. Chomczynski, P., Sacchi, N. (1987) Anal. Biochem. 162, 156-159.

4. Crouse, G. F., Frischauf, A., Lehrach, H. (1983) Methods in Enzymology 101, 78-89.

5. Sanger, F., Nicklen, S., Coulson, A.R. (1977) Proc. Natl. Acad. Sci. U.S.A. 74, 54635467.

6. Feinberg, A. P.,Vogelstein, R. (1983) Anal. Biochem. 132, 6-13.

7. Brown, N. A., Steofko, R. E., Uhler, M. D. (1990) J. Biol. Chem. 265, 13181-13189.

8. Okayama, H., Chen, C. (1987) Mol. Cell. Biol. 7, 2745-2752.

9. Campbell, V.W., Del Valle, J., Hawn, M., Park, J., Yamada, T. (1989) Am. J. Physiol. 256, G631-G636.

10. Strader, C. D., Sigal, I.S., Dixon, R. A. F. (1989) FASEB J 3, 1825-1832.

11. Mitsuhashi, M., Mitsuhashi, T., Payan, D. B. (1989) J. Biol. Chem. 264, 18356-18362.

12. Chew, C., Brown, M. R. (1989) Biochim. Biophys. Acta 888, 116-125. 